\title{
A TERMELŐI ÉRTÉKESÍTŐ SZERVEZETEK SZEREPE A VIDÉK GAZDASÁGÁBAN
}

\author{
Panyor Ágota - Szebelédi Krisztina
}

\begin{abstract}
Absztrakt: A kereslet koncentrálódásának, az áruházláncok térnyerésének következtében a mezőgazdasági termelők egyre kiszolgáltatottabbak a felvásárlókkal, feldolgozókkal szemben. Ezért a zöldség-gyümölcs ágazat hatékony müködése érdekében a termelöknek együttesen szükséges fellépniük, mely fellépés egy lehetséges formája a Termelői Értékesítő Szervezet (TÉSZ). Ezen szervezetek nemcsak a termelők, hanem a vidékgazdaság tekintetében is fontos szerepet töltenek be. Kutatásunkban a Garden TÉSZ Kft. kapcsán vizsgáljuk a szövetkezés nyújtotta gazdasági, technológiai, személyes előnyöket, valamint gátló tényezőit. A tagokkal, valamint az ügyvezető igazgatóval készített interjú alapján elmondható, hogy a szövetkezet által kínált biztos felvevőpiac, illetve post harvest tevékenység a legfontosabb előny a gazdálkodók számára. Emellett a szövetkezet hozzájárul a vidéki foglalkoztatás bővítéséhez is.
\end{abstract}

\begin{abstract}
Due to demand concentration and supermarket expansion, agricultural producers are more and more vulnerable to purchasers and processors. So that fruits-vegetables branch could operate effectively, agricultural producers should act jointly where Producer Organisation [Termelöi Értékesítő Szervezet (TÉSZ)] is a possible form of this. These organisations play a significant role not only for agricultural producers but also for rural economy. In our research we examine the economic, technological and personal benefits as well as the inhibitory factors of cooperation via Garden TÉSZ Ltd. On the basis of the interview with the members and the executive director we can state that the most important advantages for the farmers are the secure outlet market provided by the cooperative and the post harvest activity. Furthermore, the cooperative also contributes to the expansion of rural employment.
\end{abstract}

Kulcsszavak: integráció, termelői értékesítő szervezet (TÉSZ), termelői kockázat, vidékgazdaság

Keywords: integration, producer organisation, producer risk, rural economy

\section{Bevezetés}

Magyarország adottságai kiválóak a kertészeti termelés müvelésére. Klímánk, a napsütéses órák száma, a csapadék- és vízviszonyok, valamint talajaink és felszíni adottságaink kitünő erőforrások. A kertészeti ágazat szerepe fokozottan munkaigényes jellege miatt egyre inkább felértékelődik hazánkban és az Európai Unióban egyaránt. Országunk a piaci lehetőségeket tekintve is kedvező földrajzi fekvésű, hiszen Közép-Kelet-Európa centrumában helyezkedik el.

Hazánk Európai Uniós csatlakozásra való felkészülése alapvető változásokat eredményezett az ország zöldség-gyümölcs ágazatában. Ugyanakkor ezeket a változásokat nem csak az uniós szabályozások, hanem a piaci folyamatok is indokolták. A kisgazdaságok kertészeti ágazatban betöltött szerepe különösen fontos, többek között a korábban kialakult háztáji gazdaságoknak, a nagy élőmunka igénynek, valamint a területegységre eső magas termelési értéknek köszönhetően. $\mathrm{Az}$ összességében jelentős árualappal rendelkező kistermelőknek összefogásra kellett/kell törekedniük a kereskedelmi láncok megjelenésének, valamint a nagybani piacok térvesztése révén a kereslet koncentrálódásának következtében. Összefogás nélkül a termelök nagy része kiszolgáltatott szereplöje a piaci viszonyoknak, 
megfelelően szabályozott integrációk nélkül sok egyéni termelőnek nincs esélye a piaci versenyben.

„A termelöi értékesítő szervezet (TÉSZ) a zöldség-gyümölcs ágazatban valamely zöldség-gyümölcs termék vagy termékcsoport termelési, feldolgozási, tárolási, áruvá készítési, és értékesítési folyamatainak közös szervezésére létrehozott szövetkezés” (Felföldi, 2005). „A termelői csoport (TCS) a termelői szerveződések azon formája, amely a tagjai számára egy-egy termék (termékcsoport) piaci értékesítéséhez kapcsolódó követelmények és feltételek megteremtésére, az ezzel összefüggő szolgáltatási tevékenységek kialakítására és koordinálására jön létre" (Felföldi, 2005).

A termelöi értékesítő szervezet és a termelői csoport müködésének lényege valójában megegyezik, azonban a két fogalom mégis eltér egymástól. Sem a TÉSZ, sem a TCS nem egy önálló jogi forma, hanem egy elismerési folyamat során megszerzett cím. Alapjuk egy jól müködő szövetkezet vagy gazdasági szervezet, melynél alapkritérium, hogy az érintett ágazatban egy vagy több termék előállításával foglalkozzanak, rendelkezzenek az agrárpolitikáért felelős miniszter elismerésével és elfogadott müködési programmal. Tehát az elismerésnek előzetes és végleges formája lehet. Ez azt jelenti, hogy TÉSZ-t nem lehet közvetlenül létrehozni, elsőként termelői csoportként kell müködnie. Ennek alapján az előzetes elismerés a termelöi csoportokra (elözetesen elismert szervezet), a végleges elismerés a termelői értékesítő szervezetekre (véglegesen elismert szervezet) vonatkozik. Az adott szervezet akkor kaphat végleges elismerést, ha az elismerés feltételeként megszabott követelményeknek megfelel. Ha ezeket a feltételeket nem képes teljesíteni, előzetes elismerésben részesül. Az előzetes elismerés célja, hogy azon termelői szerveződések müködése is megindulhasson, melyek nem minden elismerési feltételnek - pl. árbevétel, taglétszám - tudnak megfelelni (Felföldi, 2005).

A termelöi csoport elismerésének feltétele, hogy taglétszáma minimum 15 termelő legyen, legalább 1,5 millió forint értékü jegyzett tőkével rendelkezzen, és a tagok által megtermelt termékek értékesítéséből származó éves nettó árbevétel elérje a 100 millió forintot. Termelői csoportként csak szövetkezet ismerhető el (42/2015. (VII. 22.) FM rendelet). A TÉSZ-ként történő elismeréshez szintén legalább 15 alapító tag szükséges, továbbá, hogy a termelő tagjai által megtermelt termékek értéke az elismerési kérelem benyújtását megelőző egy évben meghaladja a 250 millió forintot. Termelői értékesítő szervezetként szövetkezet vagy gazdasági társaság ismerhető el (50/2017. (X. 10.) FM rendelet). A termelői csoportok elismerésének feltételeit a 42/2015. (VII. 22.) FM rendelet, míg a termelői értékesítő szervezetek elismerésének szabályait az 50/2017. (X. 10.) FM rendelet tartalmazza.

\section{A termelői együttmüködések számának változása a rendszerváltás után Magyarországon}

A Magyarországon létrejött termelői szervezetek a magyar zöldség-gyümölcs ágazat rendszerváltást követő legfontosabb strukturális változását jelentik. E szerveződéseknek a létjogosultságát és sikerét az Európai Unió gazdasági gyakorlata 
igazolja. Több zöldség- és gyümölcstermelö tagország (Hollandia, Spanyolország, Franciaország) e szervezetek felépítésével teremtette meg mai gazdasági sikerét. Magyarország Uniós csatlakozásával nyilvánvalóvá vált, hogy a zöldség-gyümölcs ágazat szereplőinek, így a termelőknek is az Unió csak a TÉSZ-eken keresztül nyújt támogatást (Dorgai, 2010). Fontos kiemelni, hogy az Európai Unió zöldséggyümölcs piacszabályozásában a friss zöldségek és gyümölcsök a kevésbé szabályozott termékek közé tartoznak. A piacszabályozás nem határoz meg mennyiségi korlátokat, kvótákat, ezáltal a termelés szabadon növelhető vagy csökkenthetö, a piaci viszonyoknak megfelelően. Azonban szigorú minőségi követelményeknek kell eleget tenni, mely azt jelenti, hogy egyrészt a marketing oldaláról, másrészt a minőségbiztosítás oldaláról kell a piaci versenyben helytállni (Dorgai, 2010; Kristóf et al., 2005).

Magyarországon az első Termelöi Értékesítő Szervezetet 1999-ben ismerte el a Földmüvelésügyi és Vidékfejlesztési Minisztérium a 25/1999. (III. 5.) FVM rendelet megjelenésével. A rendelet a várt áttörést nem hozta meg, 2001 végén mindössze 11 szervezet rendelkezett elismeréssel. Ebben az időszakban problémát jelentett, hogy a gazdák esetenként a TÉSZ-t és a TSZ-t (a szocialista rendszer termelőszövetkezete) azonos tartalommal kezelték, illetve az állami szerepvállalás sem segítette a szövetkezést. A TÉSZ-ek megalakulásának és müködésének támogatására csak 2002-ben állt rendelkezésre pénzügyi alap. Az Unióhoz való csatlakozás előtti évben már 68 TÉSZ müködött hazánkban (Dorgai, 2010).

A TÉSZ-ek fejlődésének 1999-2003 közötti szakaszát Dudás és Juhász (2013) négy szakaszra osztotta. 1999-2002 között a kezdeti nehézségek szakasza, 20022004 között a csatlakozási csúcs, 2005-2009 között a koncentráció, míg a 2010-től napjainkig eltelt időszak a stagnálás szakasza. A kezdeti nehézségek szakaszában a gazdák a TÉSZ fogalmát a szocialista rendszer termelőszövetkezetével (TSZ) azonosították, továbbá a jogi környezet sem segítette az együttmüködési forma elterjedését, így fenntartásokkal kezelték a szövetkezést. Ebben a szakaszban lassan alakultak ki a TÉSZ-ek, 2002 végére mindössze egy szervezet rendelkezett végleges elismeréssel. A csatlakozási csúcs időszakában az unió nyújtotta magas támogatási lehetőségek és a szövetkezést népszerüsítő kampánynak köszönhetően gyors ütemben megnőtt az előzetesen elismert TÉSZ-ek száma. A csatlakozás évében 87 elözetesen és 8 véglegesen elismert TÉSZ müködött Magyarországon. A koncentráció szakaszában a véglegesen elismert TÉSZ-ek száma lassan gyarapodott, de az előzetesen elismertek száma nagymértékü csökkenésnek indult. Ennek oka, hogy 2008-ban jelentös változások következtek be az EU-reform hatására, ugyanis 2009 áprilisában többségében lejárt az előzetesen elismert szervezetek elismerési időszaka, melynek végére teljesíteniük kellett a végleges elismerés feltételeit. Amennyiben nem teljesítették a végleges elismerés feltételeit, akkor csatlakozniuk kellett egy már véglegesen elismert TÉSZ-hez. A változások eredményeként 2009ben az előzetesen elismert szervezetek közel fele elnyerte a termelöi szervezet minősítést, négy pedig megszűnt. 2005 és 2010 között a fejlődés ellentmondásos volt. Míg a termelői csoportok száma csökkent, addig a termelői értékesítő szervezeteké növekedett. A termelői csoportok száma 2009 után emelkedett, 2010- 
ben számuk elérte a 48-at, viszont 2013 után 2017-ig ismét a csökkenés volt rájuk jellemző. A termelői értékesítő szervezetek számának alakulásában 2010-től jelentkezett változás. Számuk - a 2013-as év kivételével - folyamatosan nő (DudásJuhász, 2013; Kovács, 2017). Az 1. ábra (a TÉSZ-ek fejlődésének szakaszait is szemléltetve) a termelői csoportok és termelői szervezetek számának évenkénti változását szemlélteti.

\section{1. ábra: A TÉSZ-ek számának változása 1999-2018 között}

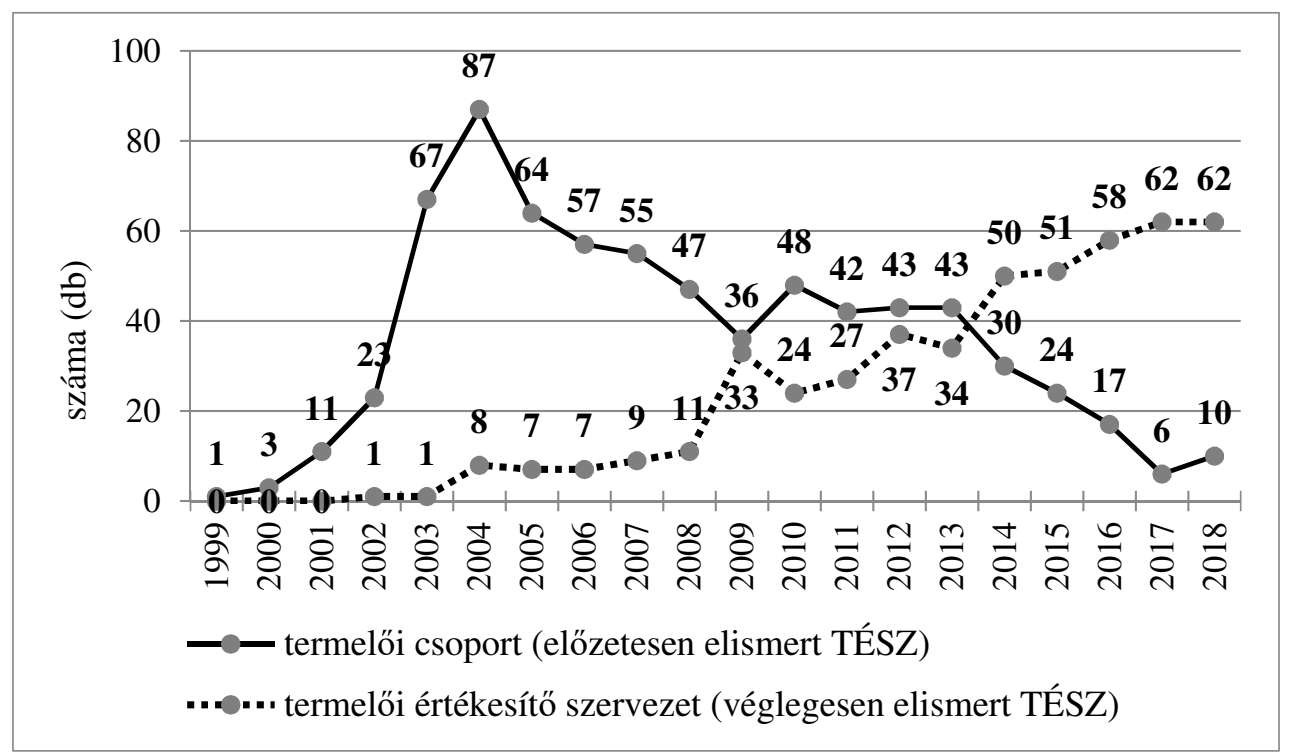

Forrás: Dorgai, 2010; Juhász et al. (2017), Internet 1 (2014), Internet 2 (2014), Internet 3 (2017), Internet 4 (2017), Internet 5 (2017) alapján a szerzők szerkesztése

\section{A mezőgazdasági termelés kockázatai}

Mint minden gazdasági tevékenység, a mezőgazdasági termelés is kockázattal jár. Azonban a többi tevékenységhez képest a mezőgazdasági ágazat nagyobb mértékü kockázatokat von maga után, föként, ha egyéni termelőként gazdálkodunk. Ennek oka elsősorban az időjárástól való fokozott függés és az ebből adódó hozamok csökkenése, növekedése, illetve a változó kínálat okozta áringadozás. A leírtak alapján a mezőgazdaságban két alapvető kockázattípust különböztetünk meg: termelési és árkockázatot. Emellett számos más kockázati tényező ismert, melyeket a következőkben mutatunk be (Kovács, 2009).

A zöldség- és gyümölcstermesztés szempontjából az éghajlati tényezők közül elsősorban a fény, a hőmérséklet és a csapadék meghatározó. Leginkább ezek a tényezők szabják meg a termeszthető növények körét, a termelési ciklusokat, a vetésszerkezetet és az arányokat. A mezőgazdasági termelés idényszerüsége a munkaerővel szemben változó igényeket támaszt. Főként a növénytermesztésben jellemzőek nagy munkacsúcsok és termelési holt időszakok. Ebből adódóan a zöldség- és gyümölcstermesztés foglalkoztatásra gyakorolt hatása is nagymértékü (Szemes-Zsuffa, 1970). 
Az időjárás befolyásolhatatlansága mellett a legtöbb kockázati tényező a piaci müködésből ered. Ezen kockázati tényezők közül a mezőgazdasági alapanyagok termelése sajátos helyet foglal el, mert a termelés adott időponthoz kötődik (stockjellegü), viszont a termékek fogyasztása folyamatos (flow-jellegü). A friss áruk iránti fogyasztói igény miatt a termékek biztosítása csak időben és minőségben szigorúan szervezett termeltetéssel valósítható meg (Regős, 2012).

Az egyéni termelőket érintő kockázatok nagy része a fent említettek mellett piaci méretükből fakad. A mezőgazdasági termelök piaci ereje általában kicsi, egyikük sem képes egyedül befolyásolni az általa megtermelt zöldség vagy gyümölcs árát, így csak árelfogadó helyzetben vannak. Meghatározó az alapanyagok és termékek árának volatilitása is. Ezt egyrészt a kibocsátás mennyiségének és minőségének eltérései (pl. az időjárás változékonysága), másrészt a kereslet változásai (pl. a fogyasztók igényeinek alakulása) magyarázzák. Az alapanyagok minőségi követelményeinek való megfelelés azért is fontos, mert nemcsak a feldolgozott vagy végtermék minőségbiztosítása előírás, így azok a termelők, akik nem felelnek meg a követelményeknek, kiszorulhatnak a piacról. Az egyéni termelők esetében hátráltató tényezőt jelent az immobilitás is. Ez egyrészt azt jelenti, hogy a helyben lévő erőforrások (pl. termőföld, talajadottságok) nem helyezhetőek át kedvezőbb gazdálkodású térségekbe. Másrészt jelenti a gazdálkodó helyhez kötöttségét, hiszen a család, a gazdálkodás épületei sem áthelyezhetőek (Tömpe, 2000; Regős, 2012).

A mezőgazdasági termelést érintő kockázatok között meg kell még említeni az intézményi (pl. állami támogatások) és a szabályozási (pl. környezeti és egészségügyi elöírások) kockázatot is. Kockázatot jelenthet továbbá a kamat- és árfolyamváltozásból eredő bizonytalanság; a munkaerő minősége; a gazdálkodók képzettségének szintje, tapasztalata, attitüdje (Regős, 2012).

\section{A termelöi együttmúködések hozzájárulása a vidék gazdaságának fenntartásához és fejlesztéséhez}

Általánosságban a mezőgazdasági szövetkezetek létrehozásának szükségessége alapvetően három tényezőtől függ: a piac szerkezetétől (monopolszervezetek jelenléte); a mezőgazdasági termék jellemzőitől (pl. romlandóság); és az adott terméknek a gazdálkodó jövedelmében betöltött szerepétől (mennyire fö vagy melléktermék) (Szabó, 2011). Azonban a termeléshez szükséges alapanyagok, eszközök ára növekszik, és ezt a növekedést a mezőgazdasági termékek ára nem követi. A nagyvállalatok, kereskedelmi láncok nemcsak nagy tőkeerővel, hanem erős érdekérvényesítő képességgel rendelkeznek, ezért a kisebb termelők számára kedvezőtlen árviszonyokat tartanak fenn. Az értékesítési láncok folyamatos rendelkezésre állást (megfelelő minőség és mennyiség, rövid határidő) kívánnak meg a termelőktől (Kajner, 2007). Ezek alapján elmondható, hogy a termelők rá vannak szorulva a szövetkezés által nyújtott gazdasági és nem gazdasági előnyökre egyaránt, mert egyenként még a relatíve nagyobb termelők is gyenge és kis alkuerővel rendelkeznek a piacon a velük szemben álló partnerekkel (kiskereskedelmi láncokkal, feldolgozókkal, felvásárlókkal) szemben. A 2. ábra a szövetkezések gazdasági előnyeit szemlélteti. Alapvető előnyt jelent az olcsóbb és egyszerübb 
inputanyag elérés, a nagyobb árumennyiség feletti rendelkezés, és ezáltal a piaci ellensúlyozó erő kialakítása, mely a piac szabad verseny irányába való elmozdítását eredményezheti (ún. kisugárzó árhatás) (Szabó-Barta, 2014). A szövetkezés által javul a gazdálkodók értékesítési biztonsága és alkupozíciója, illetve tranzakciós költségeik, piaci és technológiai kockázatuk csökken (Glatz, 2008; Szabó, 2011).

\section{2. ábra: A szövetkezetek által nyújtott gazdasági haszon formái}

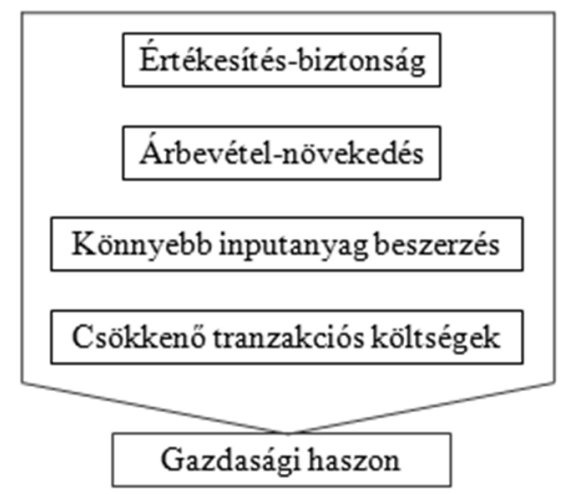

Forrás: (Orbán-Székely, 2017) alapján a szerzők szerkesztése

A szövetkezetek gondoskodnak új felvásárlók, piacok kereséséröl és megszerzéséről, és informálják a gazdálkodókat a fogyasztói igényekről. Technológiai felszereltségükkel növelhetik a termékek hozzáadott értékét. A szövetkezetek a tagok társadalmi pozícióját erősítik: amellett, hogy növelik a tagok jövedelmét, a közösséghez való tartozás érzésével növelik az együttmüködési hajlandóságot, elősegítve ezzel a bizalom és az informális kapcsolatok erősítését a tagok és a szervezet között egyaránt (Szabó, 2011).

Mint már korábban említettük, a szövetkezetek hozzájárulnak a mezőgazdasági termelés megtartásához, hiszen amíg a nem szövetkezeti keretek között müködö vállalkozások általában azokban a régiókban jönnek létre, ahol a legjobb feltételeket találják meg a termeléshez, addig a termelői szerveződések azon a földrajzi területen alakulnak meg, ahol a termelők élnek, ahol a termelést végzik. Emellett a helyi közösségek helyben maradása, a foglalkoztatás lehetőségei ezen együttmüködésektől is függnek, különösen igaz ez a hátrányos helyzetü térségekben (Dorgai, 2005). A mezőgazdaság fejlesztése, a természeti környezet védelme a vidéki térségek fejlesztésének bázisát jelentik, de azokkal együtt csak más tényezők megléte biztosítja a vidék sikerét, ezért nem lehet hosszú távon versenyképesnek maradni csak a természeti-földrajzi adottságokra alapozva (Kis, 2008).

\section{Anyag és módszer}

Primer kutatásunk keretében strukturált interjút készítettünk egy kiskőrösi vállalat, a Garden TÉSZ Kft. ügyvezető igazgatójával és 16 tagjával. A megkérdezett gazdálkodók kiválasztása nem volt eleve meghatározott. A kérdések elsősorban a 
szövetkezet által nyújtott gazdasági, technológiai, és személyes előnyökre, illetve a TÉSZ működésében felmerülő problémákra vonatkoztak.

\section{Eredmények és értékelésük}

A megkérdezett termelők kivétel nélkül termékeik eladhatósága, a biztos felvevőpiac okán csatlakoztak a TÉSZ-hez. Emellett többen válaszolták a kényszerből való belépést, mert nem tudták áruikat állandó vevőnek eladni. A TÉSZ fontos előnyeként említették a közös infrastruktúra (hütőházak) és eszközök (ládák, csomagolóanyag) meglétét is. Elmondták, hogy termékeik eltarthatósági, raktározási problémáiból és az árak kiszámíthatatlan alakulásából eredően egyéni termelőként nem tudnának helyt állni a piacon.

A megkérdezettek többsége úgy ítélte meg, hogy a TÉSZ fejlődésének megkönnyítése érdekében a raktározási és csomagolási kapacitás bővítésére lenne szükség, továbbá, hogy az egyes munkafolyamatok elvégzéséhez biztosított legyen bizonyos számú munkavállaló. Saját tevékenységük esetében a betakarítások idején a TÉSZ által biztosított munkavállalókra lenne szükség. A termelői szerveződések megalakulásának, az ezekhez történő csatlakozásnak gátló tényezőiként mindenki a gazdálkodók egymás közötti bizalom hiányát és az együttmüködési hajlandóság alacsony fokát említette. A megkérdezettek mindegyike szerint az együttmüködésekhez csatlakozók számát az állam által nyújtott pénzügyi támogatásokkal (pl. gépbeszerzés, földvásárlás támogatása) lehetne növelni. A termelői szerveződés részéről pedig magasabb felvásárlási árakra lenne szükség.

A TÉSZ ügyvezető igazgatójának tapasztalatai szerint, hasonlóan a tagok véleményéhez, a termelők számára a TÉSZ által kínált biztos felvevőpiac a legfontosabb gazdasági és személyes előny. A technológiai előnyök közül főként az jelent nagy segítséget a gazdálkodóknak, hogy a betakarítás után a TÉSZ-nél lehetőség van termékeik tárolására, hütésére.

Megkérdeztük, hogy az igazgató véleménye szerint mely üzemen belüli és üzemen kívüli tényezők befolyásolják leginkább az értékesítés sikerességét. Az üzemen belüli tényezők vonatkozásában a post harvest tevékenységet, míg az üzemen kívüli tényezők esetében a támogatásokat emelte ki. A post harvest tevékenységek közül legfontosabb az anyagmozgató és feldolgozó gépek megléte, ugyanis ezek automatizáltságának köszönhetően az esetlegesen felmerülő kézi munkaerő helyettesítése nem okoz gondot. A vissza nem térítendő támogatások beruházások kivitelezése esetén - lehetővé teszik a méretgazdaságossági potenciálok kihasználását. A pénzügyi támogatás mellett hangsúlyozta, hogy a TÉSZ-eknek (a sajátjuknak is) egyfajta munkaerő bázist kellene kialakítani és fenntartani, amellyel a szezonálisan jelentkező mezőgazdasági munkaerőt - főképp a földmunkák és a szedések időszakában - a tagok számára biztosítani tudnák. Ezáltal a gazdálkodóknak szervezett módon, megbízható munkaerőt kínálnának, illetve további munkalehetőséget teremtenének a helyi lakosoknak.

A vezető véleménye szerint a bizalom hiánya gátolja leginkább az együttmüködésekhez csatlakozók számát, illetve, hogy az idősebb termelők nehezen győzhetőek meg a szervezetbe való tömörülés előnyeiröl. Tapasztalatai alapján a 
bizalom hiánya abban mutatkozik meg, hogy a gazdálkodók többsége nem szeretné a többi termelővel közösen használni a TÉSZ tulajdonában lévő eszközöket, gépeket. Ezenkívül a gazdálkodók attól tartanak, hogy a TÉSZ tagság kritériumainak (pl. mennyiségi és minőségi elöírás, adatszolgáltatás, a TÉSZ müködési költségéhez való hozzájárulás) nehéz megfelelni. Ehhez kapcsolódóan fontos, hogy a TÉSZ betartsa a termelővel megbeszélteket az átvett áru mennyiségében, minőségi követelményeiben és az átvételi árban. Ugyanakkor a tagnak szintén vállalnia kell az áru mennyiségére és minőségére vonatkozó szabályokat.

A TÉSZ működésével kapcsolatban legnagyobb problémaként a termékek szezonalitásából fakadó időszakos foglalkoztatást és a termelők értékesítési fegyelmét emelte ki. Elmondta, hogy az időszakos foglalkoztatás kérdése, nemcsak a TÉSZ, hanem a gazdálkodók esetében is fennáll. A TÉSZ-nél a válogatás, osztályozás, csomagolás, a földeken pedig a termelés magas kézimunka igénye teszi szükségessé az alkalmi foglalkoztatást. Ehhez kapcsolódóan további gondot jelent, hogy a TÉSZ-nél foglalkoztatott alkalmi munkavállalók alacsony képzettségéből adódóan bizonyos időt vesz igénybe az adott munkafolyamat megfelelö elvégzésének „betanulása”. Azonban egy ilyen alkalmi munkavállalói csoport viszonylag rövid ideig hajlandó a TÉSZ-nél dolgozni, ezért a következő ilyen csoport számára újra szükség van „betanításra”, ami többlet időt igényel. A másik gond, hogy a tagok a szervezet szabályait és a tagsággal járó kötelezettségeket formailag vállalják, ténylegesen azonban nem tartják be. A tagok vállalják, hogy termékeik legalább $80 \%$-át a TÉSZ-en keresztül értékesítik, azonban a gyakorlatban más értékesítési csatornákat is igénybe vesznek. A problémát tovább erősíti, hogy a TÉSZ-en kívüli értékesítés ellenőrzésére a szervezetnek nincs lehetősége. A gazdálkodók esetében előny, hogy a TÉSZ-nek általában nagyobb mennyiséget tudnak eladni. Viszont a nagybani piacon vagy kis boltokba történő szállítás esetén magasabb áron tudják értékesíteni a terméket, ellenben ezen értékesítési csatornáknál kisebb mennyiségeket vásárolnak fel tőlük. A fentieken túl a beszerzési, értékesítési tevékenység során is adódhatnak konfliktusok, melyek legtöbbször a minőséggel és az árral kapcsolatosak. Emellett a szerződés betartásával és az ütemezéssel kapcsolatosan is akadnak problémák. A TÉSZ-nél gondot okoz az áruházak részéről jelentkező ingadozó mennyiségi igények kielégítése. Ilyenkor a megnövekedett áru mennyiséget más termelőtől szerzik be, azonban a mástól vásárolt áru lehet, hogy kevésbé megfelelő minőségü, és hiányzik az egységesség.

\section{Következtetések, összegzés}

A TÉSZ tagjai körében végzett interjú eredményei azt mutatják, hogy a gazdálkodók elsősorban gazdasági természetű okokból (biztos felvevőpiac) tagjai a TÉSZ-nek. Emellett biztonsági motivációkból (megbízhatóbb és stabilabb piacok) és szociális okokból (kapcsolat lehetősége a többi taggal) kifolyólag csatlakoztak a szervezethez. Tárolási, szállítási lehetőségeik korlátozottak, valamint nem rendelkeznek a feldolgozáshoz, csomagoláshoz szükséges eszközökkel, gépekkel. Emellett az áruházláncok által igényelt mennyiségi és minőségi követelményeket egyénileg nem tudják teljesíteni. Összességében megállapítható, hogy a termelők egyetértenek 
azzal, hogy az erősebb és szervezettebb piaci szereplőkkel (felvásárlók, feldolgozók, forgalmazók) szemben csak úgy képesek hatékonyan fellépni, ha legalább a termékértékesítést összefogva és koordináltan végzik.

Az ügyvezető igazgató meglátása szerint a gazdálkodók szervezetbe való belépését az értékesítésben jelentkező kockázatok csökkentésének lehetősége és a logisztikai háttér megléte ösztönzi. A TÉSZ müködését egyrészt a nagybani piacokon történő értékesítés nehezíti, melynek oka, hogy ezeken a piacokon számla, eredet és minőségvizsgálat nélkül is eladható az áru. Ezért előfordul, hogy a TÉSZ tagjai is ezt a fajta értékesítési utat választják, mert így azonnal készpénzhez jutnak. Másrészt problémát jelent az időszakos foglalkoztatás megszervezése is a termelés szezonalitásából és a munkavállalók hozzáállásából eredően.

Az általunk vizsgált TÉSZ müködésének sikeressége érdekében a TÉSZ-nek ingyenes tanácsadói rendszert kellene létrehozni, mely naprakész információkkal és segítséggel látná el a gazdálkodókat. A TÉSZ tanácsadók foglalkoztatásával személyre szabottan segíthetné a TÉSZ-hez csatlakozni szándékozókat, pl. a belépéshez szükséges engedélyek beszerzése kapcsán. Javasoljuk, hogy a TÉSZ motiválja a termelőket, hogy a meglévő produktumok termelése mellett hagyományőrzés, valamint a fogyasztók változó igényeinek kielégítése céljából prémium termékeket is előállítsanak. A konvencionális mezőgazdasági termelés mellett új tevékenységi körök (pl. biogazdálkodás) bekapcsolásával lehetőség nyílna a változó társadalmi igények kielégítésére, és a hozzáadott érték növelésére. Kiemelten fontosnak tartjuk, hogy a szervezet az általa biztosított pozitív előnyöket erőteljesebb mértékben hangsúlyozza, pl. gazdálkodói fórumokon való megjelenéssel, illetve a gazdálkodók számára nyílt nap szervezésével.

\section{Irodalomjegyzék}

25/1999. (III. 5.) FVM rendelet a zöldség-, gyümölcstermelői, -értékesítő szervezetekről

42/2015. (VII. 22.) FM rendelet a termelői csoportok elismeréséröl

50/2017. (X. 10.) FM rendelet a zöldség-gyümölcs termelöi szervezetekről

Dorgai L. (2005): Termelői szerveződések, termelői csoportok a mezőgazdaságban. Agrárgazdasági Tanulmányok, 4. szám, Agrárgazdasági Kutató Intézet, Budapest.

Dorgai L. (2010): Termelői csoportok és a zöldség-gyümölcs ágazatban müködö termelői szerveződések Magyarországon. Agrárgazdasági Tanulmányok, 6. szám, Agrárgazdasági Kutató Intézet, Budapest.

Dudás Gy., Juhász A. (2013): A magyarországi TÉSZ-ek gazdasági szerepének vizsgálata számviteli megközelítés alapján. Gazdálkodás, 57 (3): 284-287.

Felföldi J. (2005): Termelői értékesítő szervezetek (TÉSZ) a zöldség-gyümölcs ágazatban. Szaktudás Kiadó Ház, Budapest.

Glatz F. (2008): Új vidékpolitika. MTA Társadalomkutató Központ, Budapest.

Juhász A., Pólya Á., Czerván Gy., Popp J., Máhr A., Ledó F., Patay V. (2017): Jó úton haladunk? Agro Napló Országos Mezőgazdasági Szakfolyóirat, 21 (6): 37-42. <https://www.agronaplo.hu /szakfolyoirat/2017/06/gazdasag/jo-uton-haladunk> (2018. 07.03.)

Kajner P. (2007): Gazda(g)ságunk újrafelfedezése, Fenntartható vidéki gazdaságfejlesztés elméletben és gyakorlatban. L'Harmattan Kiadó, Budapest.

Kis K. (2008): Vidék, vidékgazdaság, vidékfejlesztés. Delfin Computer Informatikai Zrt., Hódmezővásárhely. 76 p. 
Kovács G. (2009): Kockázatok és kockázatkezelés a mezőgazdaságban. Agrárgazdasági Tanulmányok, 6.szám, Agrárgazdasági Kutató Intézet, Budapest.

Kovács Z. (2017): A TÉSZ-be történő belépést és az azon keresztuil történő értékesítést motiváló tényezők vizsgálatának tapasztalatai. Gazdálkodás, 61 (4): 322-324.

Kristóf L., Szenci Gy., Sztanev B. (2005): EU Piacszabályozása Kertészet. FVM Képzési és Szaktanácsadási Intézet, Budapest.

Orbán E., Székely E. (2017): Termelöi csoportok. Kézikönyv az elismerés feltételeiröl és a támogatás részleteiről. Nemzeti Agrárgazdasági Kamara, Budapest. <https://www.nak.hu/ kiadvanyok/kiadvanyok/1595-termeloi-csoport-tajekoztato-1/file> (2018. 08. 05.)

Regős G. (2012): Kockázatok a mezőgazdaságban, Köz-Gazdaság, 7 (3): 191-208. <http://unipub.lib. uni-corvinus.hu/1003/1/kg2012n3p191.pdf> (2018. 04. 24.)

Szabó G., Barta I. (2014): A mezőgazdasági termelői szervezetek - szövetkezetek jelentőségének és helyzetének változása az EU-csatlakozás után. Gazdálkodás, 58 (3): 265-269.; 272-273.

Szabó G. G. (2011): Szövetkezetek az élelmiszer-gazdaságban. Agroinform Kiadó, Budapest.

Szemes L., Zsuffa E. (1970): A termelöszövetkezetek tevékenységi körének kibövítése. Közgazdasági és Jogi Könyvkiadó, Budapest.

Tömpe F. (2000): A vertikális integráció elméleti és gyakorlati problémái az agribusinessben (a baromfivertikum példáján). Doktori $(\mathrm{PhD})$ értekezés, Gödöllő.

Internet 1 (2014): Elismert zöldség-gyümölcs termelöi szervezetek, 2014 március 31. <http://20102014.kormany.hu/download/4/b4/41000/Elismert_zoldseg_gyumolcs_termeloi_szervezetek_20 14_03_31.pdf > (2018.04.22.)

Internet 2 (2014): Elismert zöldség-gyümölcs termelői csoportok, 2014 március 31. <http://20102014.kormany.hu/download/5/b4/41000/Elismert_zoldseg_gyumolcs_termeloi_csoportok_201 4_03_31.pdf> (2018.04.22.)

Internet 3 (2017): Elismert zöldség-gyümölcs termelöi szervezetek, 2017. május 31. <http://www.kormany.hu/download/6/46/11000/Elismert_zoldseg_gyumolcs_termeloi_szervez etek_20170531.pdf> (2018.06.27.)

Internet 4 (2017): Elismert zöldség-gyümölcs termelöi csoportok, 2017. május 31. <http://www.kormany.hu/download/7/46/11000/Elismert_zoldseg_gyumolcs_termeloi_csoport ok_20170531.pdf> (2018. 06. 27.)

Internet 5 (2017): Zöldség-gyümölcs termelöi szervezetek, 2017.05.16. <http://ujkert.szie.hu/sites/ default/files/files/Z-Gy-termeloi-szervezetek.pdf> (2018. 04. 24.) 